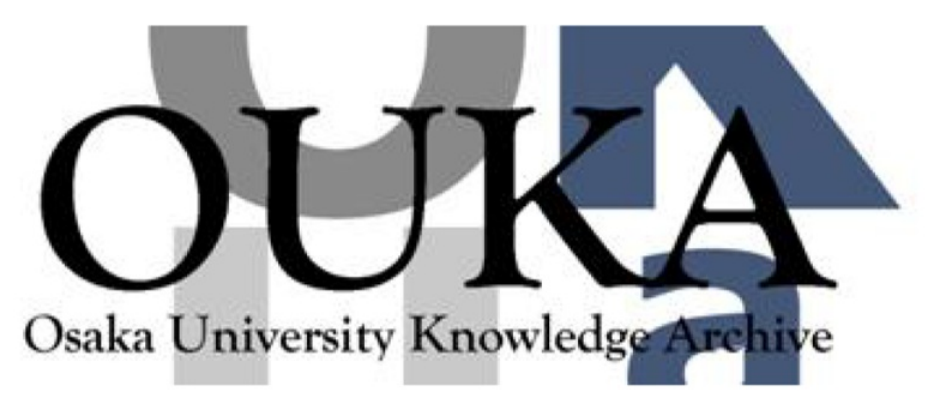

\begin{tabular}{|c|c|}
\hline Title & $\begin{array}{l}\text { Proteome analysis of human metaphase } \\
\text { chromosomes }\end{array}$ \\
\hline Author(s) & $\begin{array}{l}\text { Uchiyama, Susumu; Kobayashi, Shouhei; Takata, } \\
\text { Hideaki et al. }\end{array}$ \\
\hline Citation & $\begin{array}{l}\text { Journal of Biological Chemistry. 280(17) } \\
\text { p. } 16994-\text { p. } 17004\end{array}$ \\
\hline Issue Date & $2005-04-29$ \\
\hline oaire:version & VoR \\
\hline URL & https://hdl. handle. net/11094/79049 \\
\hline rights & $\begin{array}{l}\text { (- } 2005 \text { ASBMB. Currently published by Elsevier } \\
\text { Inc; originally published by American Society } \\
\text { for Biochemistry and Molecular Biology. This } \\
\text { article is licensed under a Creative Commons } \\
\text { Attribution } 4.0 \text { International License. }\end{array}$ \\
\hline Note & \\
\hline
\end{tabular}

Osaka University Knowledge Archive : OUKA

https://ir. Library. osaka-u. ac. jp/

Osaka University 


\title{
Proteome Analysis of Human Metaphase Chromosomes*@
}

Received for publication, November 11, 2004, and in revised form, January 21, 2005

Published, JBC Papers in Press, January 31, 2005, DOI 10.1074/jbc.M412774200

\begin{abstract}
Susumu Uchiyama $\$$, Shouhei Kobayashi $\$ \S$, Hideaki Takatał, Takeshi Ishihara $\$$, Naoto Hori Tsunehito Higashił, Kayoko Hayashihara Toshifumi Takao**, Sachihiro Matsunaga

From the $\ddagger$ Department of Biotechnology, Graduate School of Engineering, and the **Institute for Protein Research, Osaka University, Suita 565-0871, Japan and \|Bruker Daltonics K. K., Yokohama 221-0022, Japan
\end{abstract}

DNA is packaged as chromatin in the interphase nucleus. During mitosis, chromatin fibers are highly condensed to form metaphase chromosomes, which ensure equal segregation of replicated chromosomal DNA into the daughter cells. Despite $>1$ century of research on metaphase chromosomes, information regarding the higher order structure of metaphase chromosomes is limited, and it is still not clear which proteins are involved in further folding of the chromatin fiber into metaphase chromosomes. To obtain a global view of the chromosomal proteins, we performed proteome analyses on three types of isolated human metaphase chromosomes. We first show the results from comparative proteome analyses of two types of isolated human metaphase chromosomes that have been frequently used in biochemical and morphological analyses. 209 proteins were quantitatively identified and classified into six groups on the basis of their known interphase localization. Furthermore, a list of 107 proteins was obtained from the proteome analyses of highly purified metaphase chromosomes, the majority of which are essential for chromosome structure and function. Based on the information obtained on these proteins and on their localizations during mitosis as assessed by immunostaining, we present a four-layer model of metaphase chromosomes. According to this model, the chromosomal proteins have been newly classified into each of four groups: chromosome coating proteins, chromosome peripheral proteins, chromosome structural proteins, and chromosome fibrous proteins. This analysis represents the first compositional view of human metaphase chromosomes and provides a protein framework for future research on this topic.

Chromosome formation during mitosis ensures the equal and appropriate segregation of genomic information into daughter cells (1). This surprisingly well organized process was first precisely described by Flemming in 1882 (2), and its structure has been investigated by numerous researchers. A metaphase chromosome consists of two DNA molecules and chromosomal proteins that are further divided into histones and non-histone pro-

* This work was supported in part by special coordination funds from the Ministry of Education, Culture, Sports, Science, and Technology of Japan (to K. F.). The costs of publication of this article were defrayed in part by the payment of page charges. This article must therefore be hereby marked "advertisement" in accordance with 18 U.S.C. Section 1734 solely to indicate this fact.

S The on-line version of this article (available at http://www.jbc.org) contains Supplemental Figs. S1-S9 and Supplemental Tables S1-S3.

$\S$ Both authors contributed equally to this work.

ๆ Present address: Inst. for Microbiological Diseases, Osaka University, Suita 565-0871, Japan.

t To whom correspondence should be addressed. Tel.: 81-6-68797440; Fax: 81-6-6879-7441; E-mail: kfukui@bio.eng.osaka-u.ac.jp. teins $(1,3)$. Histones and their structural roles have been well characterized, including their post-translational modifications (3-8). Several studies were also carried out to elucidate the vital role of non-histone proteins in chromosome structure and function. Laemmli and co-workers (9-11) and Earnshaw and coworkers (12) carried out pioneering work, and using electron microscopy in combination with extensive biochemical analyses, they suggested the existence of a proteinaceous chromosome scaffold to which the DNA is tethered in a loop formation based on their observation of histone-depleted chromosomes. Two proteins (topoisomerase II $\alpha$ and SMC2) that constitute the scaffold were discovered through these studies $(11,12)$, although the contribution of topoisomerase $\mathrm{II} \alpha$ to the metaphase scaffold is still controversial (13-16). Several attempts have also been previously made to identify chromosomal proteins (17-20), and chromosome passenger proteins and proteins located at the chromosome periphery have been reported. In addition, some specially localized proteins in centromeric and telomeric regions have been reported (21-23). During the last decade, significant progress using mitotic extracts from frog eggs led to the identification of a condensin complex as an essential factor in chromosome condensation $(24,25)$. Despite the extensive investigation on the chromosomal proteins in the past, a fundamental question remains still unanswered. What is the global protein composition of the chromosome? This situation originates from the experimental difficulty in isolating intact chromosomes in large quantity for protein analyses given that chromosomes are formed only in a short period during the mitotic stage of the whole cell cycle in a few dividing cells.

To answer this question, the identity and localization of proteins constituting the chromosomes must be solved. Recent mechanical analyses of chromosomes using micromanipulators also raise questions regarding the scaffold model and would benefit from a list of the constituent proteins of metaphase chromosomes $(26,27)$. Recently, we reported several isolation methods for human metaphase chromosomes in large quantities after cell cycle synchronization and preliminarily compared them with each other in terms of their morphologies and protein compositions $(28,29)$. In this study, we used comparative proteomics and localization analyses to form a complete view of the chromosome from the protein perspective. We performed proteome analyses on three types of isolated human metaphase chromosomes. First, polyamine (PA $)^{1}$ chromosomes,

${ }^{1}$ The abbreviations used are: PA, polyamine; SG, sucrose gradient; SDGC, sucrose density gradient centrifugation; IEF, isoelectric focusing; RFHR, radical-free and highly reducing; PG, Percoll gradient; PMF, peptide mass fingerprinting; MALDI-TOF, matrix-assisted laser desorption ionization time-of-flight; MS/MS, tandem mass spectrometry; hCAP, human chromosome-associated protein; PBS, phosphatebuffered saline; BSA, bovine serum albumin; HMG, high mobility group; hnRNP, heterogeneous nuclear ribonucleoprotein; CCPs, chromosome coating proteins; CPPs, chromosome peripheral proteins; CSPs, chromosome structural proteins; CFPs, chromosome fibrous proteins. 
isolated by the PA procedure, a standard preparation method for chromosomes both in biochemical and morphological studies $(9,28-30)$, were investigated in this study. Second, sucrose gradient (SG) chromosomes, purified by sucrose density gradient centrifugation (SDGC) of PA chromosomes, were prepared $(29,30)$. The proteins extracted from these preparations were separated by one-dimensional SDS-PAGE, followed by Coomassie Brilliant Blue staining. Quantitative information on proteins with molecular masses $<100 \mathrm{kDa}$ was obtained by isoelectric focusing (IEF) and radical-free and highly reducing (RFHR) $(29,31)$ two-dimensional gel electrophoresis. Electrophoretically separated proteins were identified by mass spectrometry-based proteomics. Finally, we prepared purified metaphase chromosomes, referred to as Percoll gradient (PG) chromosomes, which were purified by glycerol and Percoll density gradient centrifugation $(9,32)$. Subsequently, the localizations of several representative proteins on the chromosomes were assessed by indirect immunostaining. The identified proteins were newly classified into four groups based on their compositional characterization and localization.

\section{EXPERIMENTAL PROCEDURES}

Reagents for Proteome Analysis - Water was purified using a Milli-Q system (Millipore Corp., Bedford, MA). Digitonin was purchased from Sigma and EMD Biosciences. Water for in-gel digestion and mass spectrometry, acetonitrile, and acetic acid were purchased from Nacalai Tesque (Kyoto, Japan). Trifluoroacetic acid, Coomassie Brilliant Blue R-250, and lysyl endopeptidase were purchased from Wako (Osaka, Japan). Sequence-grade trypsin and endoproteinase Glu-C were purchased from Roche. Proteins used for molecular mass references and IPG Buffer $\mathrm{pH}$ 4-7 and IPG Buffer $\mathrm{pH}$ 6-11 were purchased from Amersham Biosciences.

Isolation of Human Metaphase Chromosomes-PA chromosomes were isolated from a synchronized human cell line (BALL-1) using a PA procedure according to previously published protocols (28) with slight modifications. The PA chromosomes were diluted in PA buffer (15 mM Tris-HCl (pH 7.2), 2 mm EDTA, 80 mm KCl, 20 mm NaCl, 0.5 mm EGTA, $0.2 \mathrm{~mm}$ spermine, and $0.5 \mathrm{~mm}$ spermidine) and collected by centrifugation at $1750 \times g$ for $10 \mathrm{~min}$. This washing procedure was repeated three times. Although chromosomes maintain their condensed structure with divalent cations such as $\mathrm{Ca}^{2+}$ or $\mathrm{Mg}^{2+}(30,33)$, PA was used in this study to avoid degradation of proteins and nucleic acids and to preserve the native chromosome structure $(28,30)$. SG chromosomes were prepared by subjecting PA chromosomes to SDGC. PA chromosomes were layered onto a linear $20-60 \%$ (w/v) sucrose gradient in PA buffer and centrifuged at $2500 \times g$ for $15 \mathrm{~min}$ in a JS-24.38 swinging rotor (Beckman Instruments). Fractions consisting of chromosomes with native morphology were assessed by optical microscopy following 4',6-diamidino-2-phenylindole staining and were combined together. SG chromosomes were then collected by centrifugation at $1000 \times g$ for $10 \mathrm{~min}$ after dilution of sucrose with PA buffer. Isolated PA and SG chromosomes were stored at $-80{ }^{\circ} \mathrm{C}$ in PA buffer containing $70 \%$ glycerol until used. As indicated in our previous study (29), synchronization by Colcemid treatment did not have a significant effect on the protein composition of the isolated chromosomes.

For PG chromosome isolation, cell culture and synchronization of HeLa S3 cells were performed using the same procedures as in the SG chromosome preparation, except for the concentration of fetal calf serum (10\% for BALL-1 cells and 5\% for HeLa S3 cells). Isolation was carried out according to the method developed previously by Laemmli and co-workers $(9,32)$. Cells were harvested at $20^{\circ} \mathrm{C}$ by centrifugation at $1500 \times g$ for $10 \mathrm{~min}$ and washed three times at $20^{\circ} \mathrm{C}$. The cells collected were hypotonically swollen in wash buffer $(7.5 \mathrm{~mm}$ Tris, $40 \mathrm{~mm}$ $\mathrm{KCl}, 1 \mathrm{~mm}$ EDTA, $0.1 \mathrm{~mm}$ spermine, $0.25 \mathrm{~mm}$ spermidine, $1 \%$ thiodiglycol, and $0.1 \mathrm{~mm}$ phenylmethylsulfonyl fluoride) at $20^{\circ} \mathrm{C}$. Hereafter, unless stated otherwise, the procedures for PG chromosome isolation were performed at $4{ }^{\circ} \mathrm{C}$. Subsequently, the cells were lysed with ice-cold lysis buffer (15 mm Tris, $80 \mathrm{~mm} \mathrm{KCl,} 2 \mathrm{~mm}$ EDTA, $0.2 \mathrm{~mm}$ spermine, 0.5 mM spermidine, $1 \%$ thiodiglycol, $0.1 \mathrm{~mm}$ phenylmethylsulfonyl fluoride, and $0.1 \%$ Empigen) on ice using a homogenizer, and the chromosomes were readily released. The lysate was layered over the exponential glycerol gradients, which were spun in a JS-24.38 rotor for $5 \mathrm{~min}$ at $200 \times g$, followed by $15 \mathrm{~min}$ at $700 \times g$. Fractions containing dispersed metaphase chromosomes were placed on a $70 \%$ glycerol cushion and spun at $3000 \times g$ for $15 \mathrm{~min}$ to recover chromosomes. Chromosomes partially purified by the procedures described above were stored at $-20{ }^{\circ} \mathrm{C}$ in storage buffer (3.75 mm Tris, $20 \mathrm{~mm} \mathrm{KCl,} 0.5 \mathrm{~mm}$ EDTA, 0.05 $\mathrm{mm}$ spermine, $0.125 \mathrm{~mm}$ spermidine, $1 \%$ thiodiglycol, $0.1 \mathrm{~mm}$ phenylmethylsulfonyl fluoride, and $0.1 \%$ Empigen) containing $60 \%$ glycerol for further purification by Percoll density gradient centrifugation. The mixture of stored chromosomes and Percoll solution was gently homogenized with a Dounce homogenizer, followed by centrifugation at $45,440 \times g$ for $30 \mathrm{~min}$ in a JS-24.38 rotor. A band containing chromosomes located at a level that was one-fifth the length of the tube measured from the bottom (Fig. S1) was diluted 3-fold in isolation buffer ( $5 \mathrm{~mm}$ Tris, $20 \mathrm{~mm} \mathrm{KCl,} 20 \mathrm{~mm}$ EDTA, $0.25 \mathrm{~mm}$ spermidine, $1 \%$ thiodiglycol, $0.1 \mathrm{~mm}$ phenylmethylsulfonyl fluoride, and $0.1 \%$ Empigen) and subsequently centrifuged at $3000 \times \mathrm{g}$ for $15 \mathrm{~min}$ to collect PG chromosomes.

Extraction of Proteins from Isolated Chromosomes-For one-dimensional SDS-PAGE analysis, isolated chromosomes were directly suspended and dissolved in SDS sample buffer (62.5 mM Tris-HCl ( $\mathrm{pH} \mathrm{6.8)}$, $5 \%$ 2-mercaptoethanol, $20 \%$ glycerol, $2 \%$ SDS, and $0.005 \%$ bromophenol blue). For two-dimensional gel electrophoresis, proteins were extracted from isolated chromosomes using the acetic acid extraction method described previously $(29,34)$. Typically, a single extraction experiment using PA chromosomes isolated from $2.8 \times 10^{8}$ BALL-1 cells yielded 500 $\mu \mathrm{g}$ of proteins, whereas PG chromosomes isolated from $2.8 \times 10^{8} \mathrm{HeLa}$ S3 cells yielded $44 \mu \mathrm{g}$ of proteins. The lower amount of proteins extracted from PG chromosomes originated mainly from the decrease in the chromosomes at each purification step. Protein aliquots were lyophilized and stored at $-80^{\circ} \mathrm{C}$ until further analysis.

Electrophoretic Separation of Chromosomal Proteins-For one-dimensional SDS-PAGE using 5-10 or 5-20\% gel, Perfect NT gel (DRC Corp., Tokyo, Japan) was used. In addition to conventional IEF twodimensional gel electrophoresis, RFHR two-dimensional gel electrophoresis was also used for the separation of chromosomal proteins covering a wide range of isoelectric points $(29,31)$. RFHR two-dimensional gel electrophoresis provides an excellent separation of highly basic proteins. The detailed procedures involved in IEF and RFHR two-dimensional gel electrophoresis analyses were described in our previous study (29).

Detection of Proteins-Proteins separated by one-dimensional SDSPAGE were stained with Coomassie Brilliant Blue and then quantified using ImageQuant (Amersham Biosciences). In addition, the quantitative information on proteins with a molecular mass lower than $\sim 100$ $\mathrm{kDa}$ was mainly obtained from two-dimensional gel electrophoresis analyses. Proteins separated by two-dimensional gel electrophoresis were analyzed with ImageMaster 2-D Elite (Amersham Biosciences). The amount of each protein was determined as a ratio to core histone H4, which was well separated from the other core histones. The molar ratios of each protein in relation to histone $\mathrm{H} 4$ were calculated from the results obtained with the smallest possible starting amounts of protein to avoid artifactual underestimation resulting from stain saturation of the bands or spots in one-dimensional SDS-PAGE or two-dimensional gel electrophoresis, respectively. Thus, under these conditions, the amount of protein has a linear relationship with the intensity of the corresponding band or spot. The relative amounts of each protein were determined by averaging more than six two-dimensional gel electrophoresis results obtained under the same conditions. In the case that several proteins were identified from a single band, the band intensity was divided by the averaged molecular masses of the identified proteins, which provided the summation of the relative molar ratio of the identified proteins.

In-gel Digestion-Pieces of the gel containing proteins of interest were excised for digestion with trypsin, lysyl endopeptidase Lys-C, or endoproteinase Glu-C using the following procedures. Gel pieces obtained from one- or two-dimensional gel electrophoresis were destained by incubation in $1 \mathrm{ml}$ of $50 \mathrm{~mm}$ ammonium bicarbonate in $50 \%$ methanol. For reductive alkylation, gels dehydrated with $100 \%$ acetonitrile for $10 \mathrm{~min}$ at room temperature were incubated for $30 \mathrm{~min}$ at $56^{\circ} \mathrm{C}$ in $25 \mu \mathrm{l}$ of $100 \mathrm{~mm}$ dithiothreitol in $100 \mathrm{~mm}$ ammonium bicarbonate, followed by replacement of the dithiothreitol solution with $25 \mu \mathrm{l}$ of $100 \mathrm{~mm}$ iodoacetamide in $100 \mathrm{~mm}$ ammonium bicarbonate and incubation for $30 \mathrm{~min}$ at $37^{\circ} \mathrm{C}$ in the dark. Gel pieces were then dehydrated in $100 \%$ acetonitrile and dried for $30 \mathrm{~min}$ in a SpeedVac (Thermo Electron Corp., Waltham, MA). Dried pieces were rehydrated for $45 \mathrm{~min}$ at $4{ }^{\circ} \mathrm{C}$ in $5-30 \mu \mathrm{l}$ of a solution of $50 \mathrm{~mm}$ ammonium bicarbonate containing 2-3 pmol of trypsin, Lys-C, or Glu-C. After incubation for $16 \mathrm{~h}$ at $37^{\circ} \mathrm{C}$, peptides were eluted with $20 \mu \mathrm{l}$ of $0.1 \%$ trifluoroacetic acid in $50 \%$ acetonitrile for 10 min at room temperature with sonication. The second and third elutions of the peptides were performed under the same conditions. The first, second, and third trifluoroacetic acid solutions were mixed to- 
gether, followed by reduction of the volume to $5 \mu$ l using the SpeedVac. Desalting of the peptides was performed with ZipTip $\mathrm{C}_{18}$ pipette tips (Millipore Corp.). After equilibration with $0.1 \%$ trifluoroacetic acid, peptides were adsorbed to the ZipTip $\mathrm{C}_{18}$ pipette tips, followed by washing with $0.1 \%$ trifluoroacetic acid and elution with $5 \mu \mathrm{l}$ of $50 \%$ acetonitrile containing $0.1 \%$ trifluoroacetic acid.

Protein Identification by Mass Spectrometry-For identification using the peptide mass fingerprinting (PMF) method, 1- $\mu$ l aliquots were deposited on an AnchorChip 384-well target plate (Bruker Daltonik $\mathrm{GmbH}$, Bremen, Germany) followed by deposition of $1 \mu \mathrm{l}$ of matrix (10 $\mathrm{mg} / \mathrm{ml} \alpha$-cyano-4-hydroxycinnamic acid in 50\% acetonitrile and $0.1 \%$ trifluoroacetic acid). Subsequently, the drops were dried up in the atmosphere. The identification of each protein after the enzymatic digestions was carried out by PMF analysis using a matrix-assisted laser desorption ionization time-of-flight (MALDI-TOF) mass spectrometer (Autoflex or Ultraflex, Bruker Daltonik GmbH) and by tandem mass spectrometry (MS/MS) analysis using a MALDI-TOF/ TOF mass spectrometer (Ultraflex) (35). In addition, an Esquire electrospray ionization MS/MS system (Bruker Daltonik GmbH) equipped with a liquid chromatography (Dionex Corp., Sunnyvale, CA) was employed for protein identification. Mass data extracted by Flex analysis (Bruker Daltonik $\mathrm{GmbH}$ ) for MALDI-TOF/TOF or by Hystar Version 2.3 (Bruker Daltonik $\mathrm{GmbH}$ ) for electrospray ionization MS/MS were analyzed using Biotools Version 2.2 (Bruker Daltonik $\mathrm{GmbH}$ ) employing the MASCOT search engine. Most proteins were identified by matching the PMF results with the NCBInr Database. Identification was considered positive when high scores were obtained from both trypsin and Lys-C or Glu-C digestions. In some cases, three to four proteins could be identified by PMF analysis of a single band. Several peptide peaks observed by MALDI-TOF mass spectrometry were further analyzed by MALDI-TOF/TOF MS/MS for identification and/or confirmation of proteins. Examples of protein identification are indicated in Fig. S5-S8.

Immunofluorescence Microscopy-Monoclonal antibodies against $\beta$-actin and histone H1 were produced for this study. The production of monoclonal antibodies against these chromosomal proteins was carried out by immunization of mice with the extracted chromosomal proteins. After screening by indirect immunofluorescence microscopy, several monoclonal antibodies were obtained. The immunoprecipitated antigen protein was identified by PMF. ${ }^{2}$ Polyclonal antibody against human chromosome-associated protein (hCAP) G was produced as described previously (36). Antibodies against BiP and hSNF2H (H-300) were purchased from Santa Cruz Biotechnology, Inc. (Santa Cruz, CA). Monoclonal antibody against Ki-67 (MIB-1) was purchased from Dako Cytomation (Glostrup, Denmark). Antibody against calreticulin was purchased from Alexis Biochemicals (Lausen, Switzerland).

Indirect fluorescent antibody staining of $\mathrm{HeLa}$ cells was performed according to a previously published method (37). HeLa S3 cells were grown on coverslips coated with poly-L-lysine (Sigma). The cells were washed with phosphate-buffered saline (PBS) and fixed with $2 \%$ paraformaldehyde (Wako) in XBE2 buffer (10 mM HEPES (pH 7.7), 2 $\mathrm{mm} \mathrm{MgCl}_{2}, 100 \mathrm{~mm} \mathrm{KCl}$, and $5 \mathrm{~mm}$ EGTA) for $15 \mathrm{~min}$ at room temperature. The fixed cells were then treated with $0.5 \mathrm{mg} / \mathrm{ml} \mathrm{NaBH}$ (Wako) in XBE2 buffer for 5 min at room temperature, rinsed twice with XBE2 buffer for $5 \mathrm{~min}$, and permeabilized with $0.5 \%$ Triton X-100 in XBE2 buffer at room temperature. After being washed twice with XBE2 buffer for $5 \mathrm{~min}$, the cells were incubated with $3 \%$ bovine serum albumin (BSA; Wako) in XBE2 buffer for $30 \mathrm{~min}$ at room temperature. Subsequently, the cells were incubated with primary antibodies, $1 \% \mathrm{BSA}$, and $0.05 \%$ Tween 20 in XBE2 buffer at room temperature for $1 \mathrm{~h}$. After being washed five times with XBE2 buffer for $3 \mathrm{~min}$, the cells were incubated with secondary antibodies, $1 \% \mathrm{BSA}$, and $0.05 \%$ Tween 20 in XBE2 buffer at room temperature for $1 \mathrm{~h}$. After being washed six times with XBE2 buffer for $3 \mathrm{~min}$, the cells were mounted with $1 \mu \mathrm{g} / \mathrm{ml}$ 4',6-diamidino-2-phenylindole in Vectashield (Vector Laboratories, Burlingame, CA) and observed under a Zeiss Axioplan 2 imaging fluorescence microscope.

Staining of metaphase chromosome spreads was performed according to previously published methods $(25,38)$. For preparation of metaphase chromosome spreads, HeLa S3 cells were treated with Colcemid (final concentration of $0.1 \mu \mathrm{g} / \mathrm{ml}$ ) for $3 \mathrm{~h}$ before harvesting. Mitotic cells, collected by tapping culture dishes, were centrifuged at $200 \times \mathrm{g}$ for 5 min at room temperature, and the harvested cells were treated with 75

${ }^{2}$ T. Higashi, S. Miyakawa, S. Uchiyama, S. Matsunaga, H. Takata, S. Fujimoto, M. Noda, A. Terauchi, T. Shimizu, M. Oda, T. Azuma, and K. Fukui, manuscript in preparation.
A

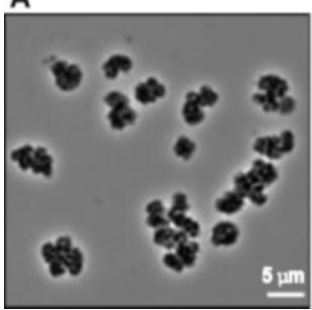

B

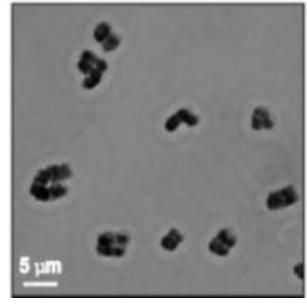

FIG. 1. Microscopic observations of isolated human metaphase chromosomes. $A$ and $B$, Giemsa staining of SG chromosomes from BALL-1 cells and PG chromosomes from HeLa S3 cells, respectively.

$\mathrm{mm} \mathrm{KCl}$ at $1.5-2.0 \times 10^{5}$ cell $/ \mathrm{ml}$ for $15 \mathrm{~min}$. The cells were spread onto coverslips using a Cytospin (Thermo Electron Corp.) and then fixed with $2 \%$ paraformaldehyde in PBS (pH 7.4) for 15 min at room temperature. After washing three times with PBS, the metaphase chromosome spreads were permeabilized in $0.2 \%$ Triton X-100 in PBS for 5 min at $4{ }^{\circ} \mathrm{C}$. After washing, the spreads were incubated with 3\% BSA in PBS for $30 \mathrm{~min}$ at room temperature. Subsequently, the spreads were incubated with primary antibodies and 3\% BSA in PBS for $1 \mathrm{~h}$ at room temperature. After washing three times with PBS for 5 min, the spreads were incubated with secondary antibodies and 3\% BSA in PBS for $1 \mathrm{~h}$ at room temperature. After being washed three times with PBS for $5 \mathrm{~min}$, the spreads were mounted with $1 \mu \mathrm{g} / \mathrm{ml} \mathrm{4}$, 6-diamidino-2phenylindole in Vectashield.

Isolated metaphase chromosomes were also immunostained according to a previously published method (37). Briefly, isolated chromosomes were diluted in XBE2 buffer and fixed by adding 0.1 volume of $8 \%$ paraformaldehyde at room temperature for $15 \mathrm{~min}$. The fixed chromosomes were spun onto poly-L-lysine-coated coverslips through XBE2 buffer containing $30 \%$ sucrose and stained as described above for indirect fluorescent antibody staining of HeLa cells.

\section{RESULTS}

Morphologies and Protein Compositions of Isolated Human Metaphase Chromosomes-PA chromosomes are free of nuclei, as previously confirmed by flow cytometry (28). Optical microscopy demonstrated that PA (29) and SG (Fig. 1A) chromosomes retained the native morphology of metaphase chromosomes. One-dimensional SDS-PAGE of PA chromosomes (Fig. 2, $A$ and $B$ ) revealed numerous protein bands spanning a broad molecular mass range in addition to reasonably intense bands of the most abundant proteins, core and linker histones. The weight percentage of histones in all of the chromosomal proteins was estimated at $60 \%, 48$ and $12 \%$ of which correspond to core and linker histones, respectively. One-dimensional SDS-PAGE indicated that the DNA-dependent protein kinase catalytic subunit $(465 \mathrm{kDa})$ had the highest molecular mass. Two intense bands corresponding to myosin II and a $130-\mathrm{kDa}$ leucine-rich protein were confirmed by one-dimensional SDS-PAGE in the higher molecular mass region (Fig. $2 B$, bands 4 and 9). The IEF two-dimensional gel electrophoresis patterns of PA and SG chromosomal proteins at pI 4-7 and 6-11 are shown in Fig. 3. The RFHR two-dimensional gel electrophoresis results for PA and SG chromosomal proteins are provided in Fig. 4 ( $A$ and $B$, respectively). PA chromosomes had a larger number of proteins compared with SG chromosomes, especially in the weak basic regions, which are indicated in Fig. 3 ( $C$ and $D$, dotted ovals). Over 200 and 150 spots were reproducibly detected for PA and SG chromosomes, respectively. A chromatin-remodeling leucine-rich protein (spot A1; molecular mass of $145 \mathrm{kDa}$ ) had the highest molecular mass and was well separated at pI 4-7 (Fig. 3, $A$ and $C$ ).

PG chromosomes also had the native morphology as observed under a microscope (Fig. 1B). As for the protein composition of PA chromosomes, histones were obviously the most abundant proteins constituting PG chromosomes. The RFHR pattern of PG chromosomes was apparently close to that of SG chromosomes.

Identification of Proteins in PA and SG Chromosomes-Most 


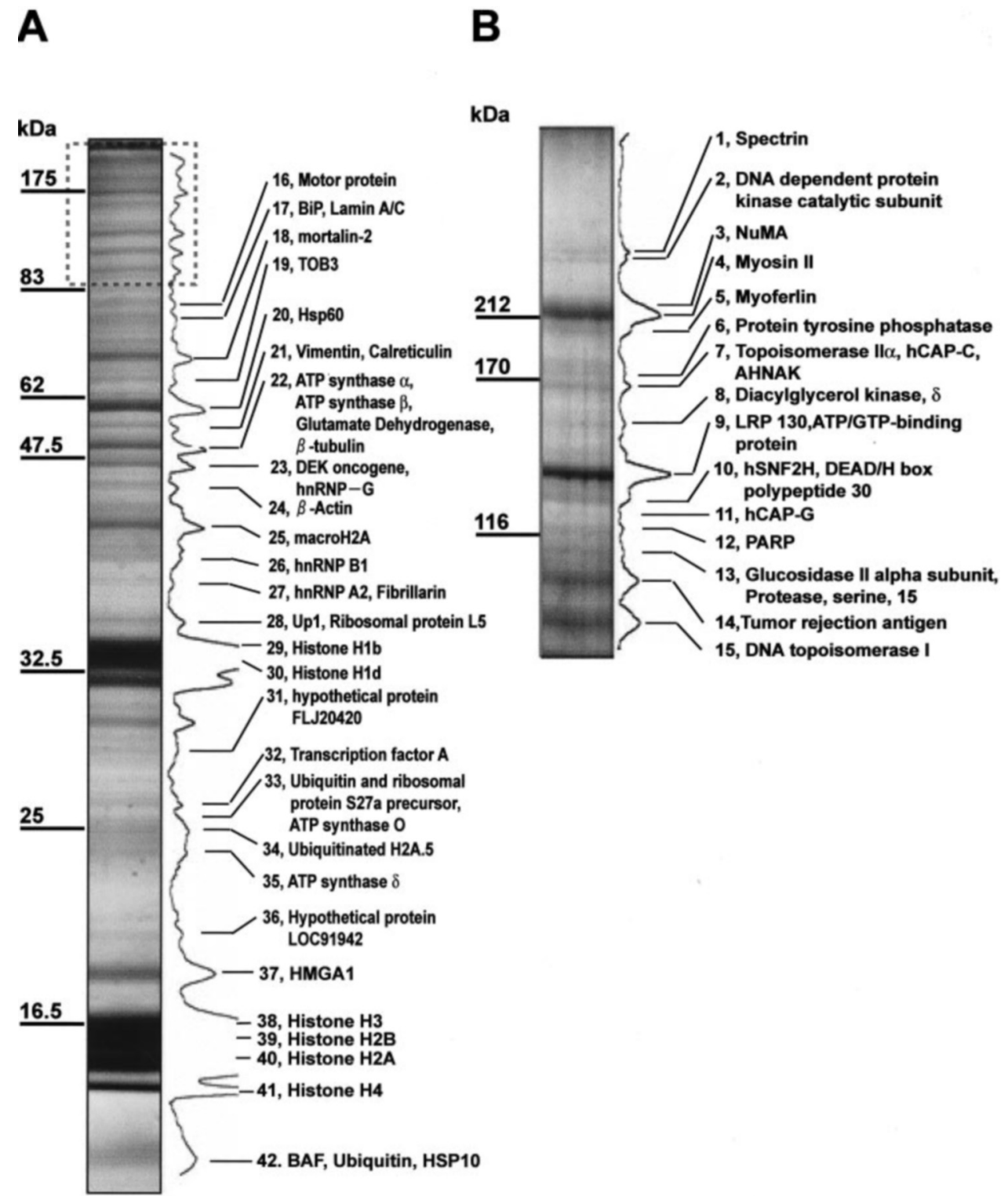

FIG. 2. One-dimensional SDS-PAGE analyses of PA chromosomes. PA chromosomal proteins were separated by one-dimensional SDSPAGE on $12 \%(A)$ and $8 \%(B)$ polyacrylamide gels and stained with Coomassie Brilliant Blue. The bands were then excised for protein identification. The same number of proteins was also used in Table S1. LRP 130, 130-kDa leucine-rich protein; hSNF2H, human SNF2H; PARP, poly(ADP-ribose) polymerase; NuMA, nuclear mitotic apparatus protein; BAF, barrier to autointegration factor.

of the intense bands or spots observed after electrophoresis were unambiguously identified. In the PA and SG chromosomes, 209 proteins were identified, only 51 of which overlapped in one-dimensional SDS-PAGE and the two types of two-dimensional gel electrophoresis. Thus, 158 proteins were identified among the PA and SG chromosomes. Generally, their amounts estimated from one-dimensional SDS-PAGE were similar to those obtained by the two-dimensional gel electrophoresis analyses. The names of the proteins, their numbers corresponding to those in Figs. 2-4, data base accession numbers, molecular masses, pI values, MASCOT scores, sequence coverage, Nuclear Protein Database accession numbers (39), and related information where available have been summarized (Tables S1-S3). The molar amount of each protein is provided per 100 histone H4 molecules. The differences in the molar amount of each protein between PA and SG chromosomes are indicated as molar ratios. One-dimensional SDSPAGE provided quantitative information on proteins with molecular masses $>100 \mathrm{kDa}$, whereas IEF two-dimensional gel electrophoresis provided information on acidic and basic pro- teins with molecular masses $<100 \mathrm{kDa}$. RFHR two-dimensional gel electrophoresis provided complementary information on basic proteins. Proteins identified in PA and SG chromosomes were classified into six groups based on their known interphase localization. The six groups were nuclear, mitochondrial, ribosomal, cytoplasmic, cytoskeletal, and unknown.

Protein Constituents of PA and SG Chromosomes-Fig. $5 A$ shows the percentages of classified proteins in PA chromosomes by number and molar amount. Mitochondrial proteins were the most abundant (37.7\%, 60:159) with regard to number. Nuclear proteins represented $29.6 \%$ (47:159), and ribosomal proteins amounted to $13.2 \%(21: 159)$ of the total proteins. Cytoplasmic proteins composed $12.0 \%$ (19:159). The molar amounts of the proteins estimated from the division of band or spot intensities by their molecular masses present an alternative view of the protein composition (Fig. 5A). Nuclear proteins represented $86.9 \%$ of the total molar amount of the PA chromosomal proteins. A conspicuous difference was due to a large amount of nuclear proteins and a small amount but substantial numbers of ribosomal, mitochondrial, and cytoplasmic proteins. 

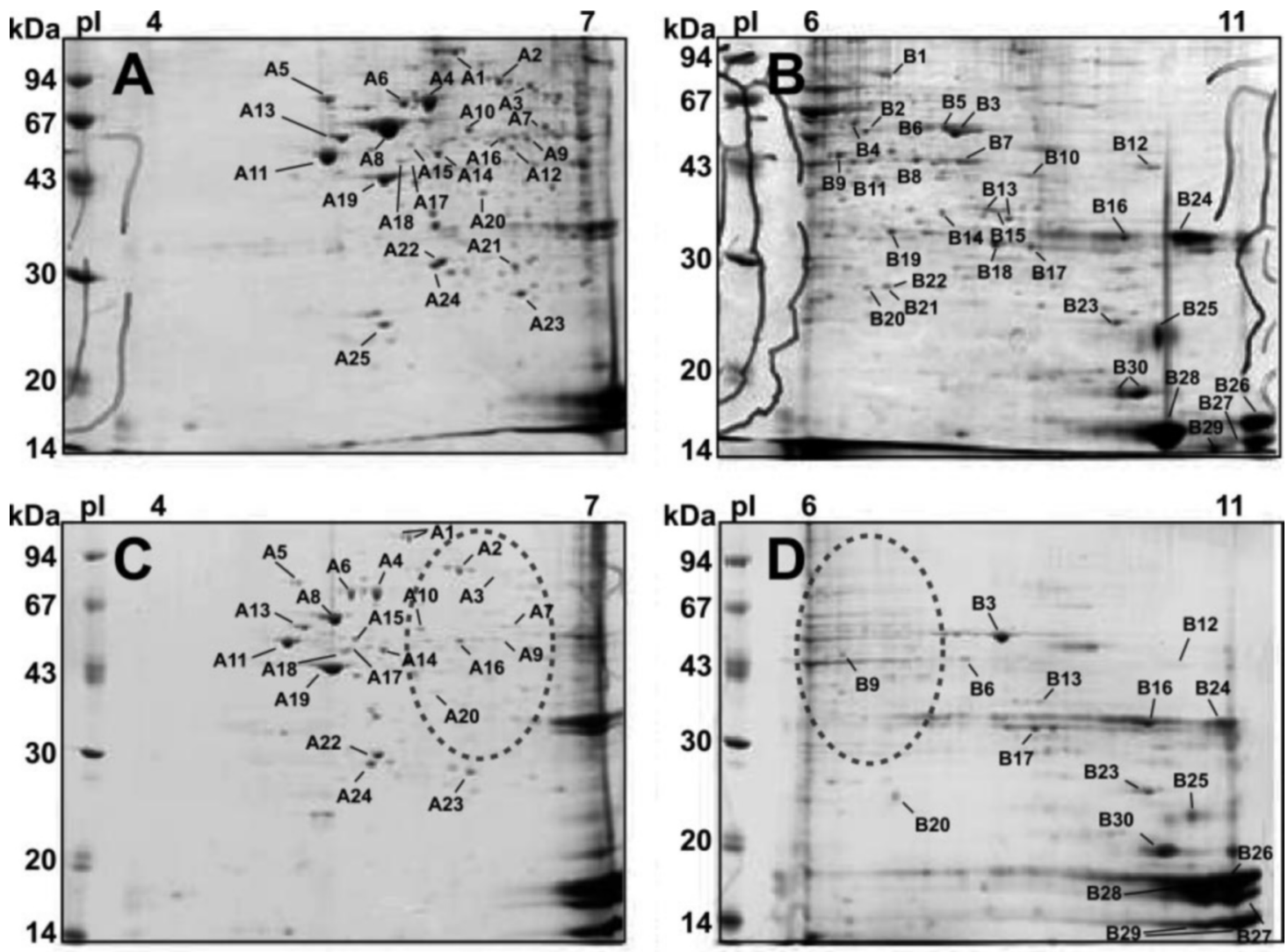

FIG. 3. IEF two-dimensional gel electrophoresis patterns of proteins from PA $(A$ and $B)$ and SG $(C$ and $D)$ chromosomes. Extracted proteins were separated by IEF on immobilized $\mathrm{pH} 4-7(A$ and $C)$ and 6-7 $(B$ and $D)$ gradients in the first dimension. They were then separated by SDS-PAGE in the second dimension. The dotted ovals in $C$ and $D$ represent the area in which the signal intensity of the spots markedly decreased after purification by SDGC.

PA chromosomal proteins contained 34.3 histone $\mathrm{H} 1$ molecules/100 histone $\mathrm{H} 4$ molecules; this value is close to that reported for the interphase nucleus $(40-42)$. The amount of high mobility group (HMG) N2 (Fig. 4A, spot R85) was 29.18 molecules/100 histone $\mathrm{H} 4$ molecules; and hence, it was the second most abundant protein following histones. HMGA1 (HMG AT hook protein-1) was present in a large amount (Fig. $2 A$, band 37; Fig. $3 B$, spot B30; and Fig. $4 A$, spots $R 81$ and R83). Ubiquitinated histone $\mathrm{H} 2 \mathrm{~A}$ was also present in a large amount (Fig. 2A, band 34; Fig. 3B, spot B25; and Fig. 4A, spot R53). Approximately one $\beta$-actin molecule was present per 100 histone $\mathrm{H} 4$ molecules (Fig. 2A, band 24; and Fig. 3A, spot A19). One-dimensional SDS-PAGE confirmed two intense bands corresponding to myosin II and a $130-\mathrm{kDa}$ leucine-rich protein in the higher molecular mass region (Fig. $2 B$, bands 4 and 9 ).

Quantitative analyses based on the comparative proteome analysis between PA and SG chromosomes provided an important perspective for the identified proteins; they could be classified into two discrete types of protein groups with low and high affinities for isolated chromosomes (Fig. 5B). Proteins with low affinities were eliminated after SDGC (spots within the dotted ovals in Figs. 3 ( $C$ and $D$ ) and $4 B$ ). For example, the mitochondrial $60-\mathrm{kDa}$ heat shock protein was largely dissociated in SG chromosomes (Fig. 3, $A$ and $C$, spot A8). The amounts of most of the mitochondrial and cytoplasmic proteins became significantly low in SG chromosomes. The 21 proteins specific to PA chromosomes were mitochondrial proteins (Table $\mathrm{S} 2$ ). On the other hand, intense spots of histones, HMGs, and $\beta$-actin (Figs. 3 and 4 ) were similar in both PA and SG chromosomes, indicating their structural roles or high affinities for isolated metaphase chromosomes. Among nuclear proteins, the amounts of several proteins, including nucleolin, decreased, but a considerable amount still remained after SDGC.

Identification of Proteins in PG Chromosomes-For further identification and characterization of chromosomal proteins essential for the chromosome structure, proteome analyses of purified metaphase chromosomes (PG chromosomes) were performed by one-dimensional SDS-PAGE (Fig. 6) and RFHR twodimensional gel electrophoresis (Fig. 7). Consequently, 107 major proteins involved in the detected bands or spots were identified (Supplemental Table S3). A sample of proteins identified in PA, SG, or PG chromosomes is given in Table I. Although 10 mitochondrial or cytoplasmic proteins were still identified from PG chromosomes, most of the mitochondrial and cytoplasmic proteins (e.g. typical mitochondrial or endoplasmic reticulum marker proteins, glutamate dehydrogenase or calreticulin, respectively) were absent in PG chromosomes. On the other hand, known chromosomal proteins such as topoisomerase II $\alpha$, condensin subunits, and inner centromere protein were frequently identified in PG chromosomes.

Localization of Representative Identified Proteins-The localizations on the chromosomes of representative proteins identified in this study were visualized by indirect immunostaining under three different cytological conditions in chromosome preparations. The three cytological conditions of isolated chromosomes in suspension (Fig. 8), chromosomes in cells (Fig. S2), and ordinary spread chromosome specimens (Fig. S3) would reflect isolated chromosomes, in vivo chromosomes, and the cytological control, respectively. Calreticulin was detected around isolated chromosomes and the cytological control, but not detected on in vivo chromosomes. This group included BiP. The other proteins except for those of this type were all localized on the chromosomes prepared under the three different 
FIG. 4. RFHR two-dimensional gel electrophoresis patterns of proteins from PA (A) and SG (B) chromosomes. The dotted oval in $B$ represents the area in which the signal intensity of the spots markedly decreased after purification by SDGC.

\section{A}
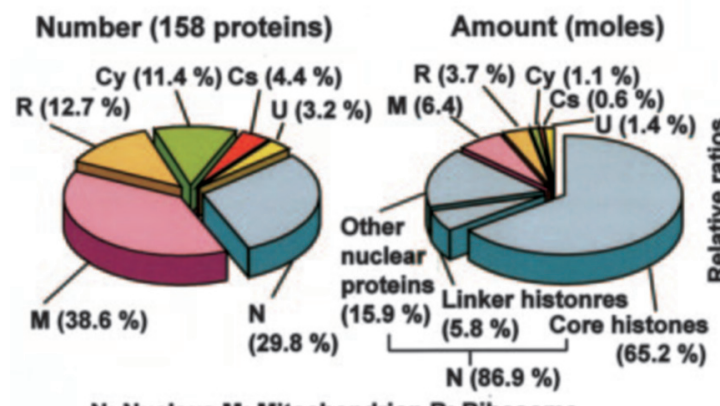

N: Nucleus M: Mitochondrion R: Ribosome Cy: Cytoplasm Cs: Cytoskeleton U: Unknown
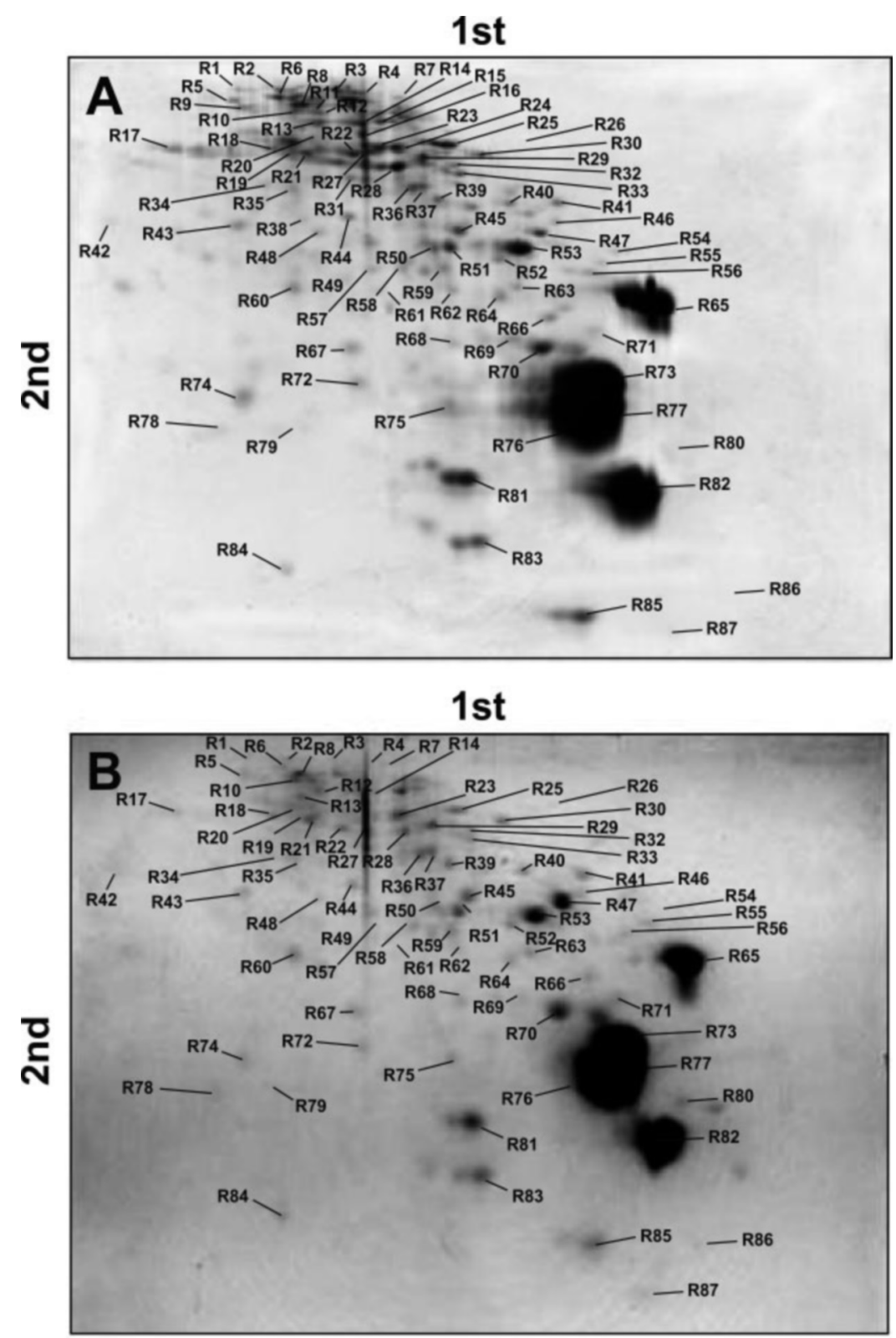

B

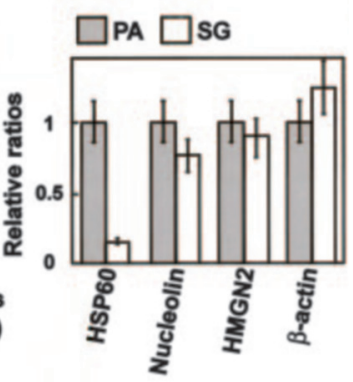

Fig. 5. Profiles of the constituent proteins of PA and SG chromosomes. $A$, the identified proteins were classified based on their known localization during interphase. Percentages are presented based on either the number of the identified proteins (left) or the molar amounts of the identified proteins (right). $B$, differences in the amounts between PA and SG chromosomes are shown for the representative proteins from the four groups. The relative amounts of proteins in SG chromosomes are indicated as the ratios to those in PA chromosomes. conditions. They were divided into two obviously different types. Ki-67 was visualized at the peripheral regions of two chromatids of all three types of chromosomes. Heterogeneous nuclear ribonucleoprotein (hnRNP) A2/B1 showed similar distribution patterns. Histone $\mathrm{H} 1$ and human SNF2H demon- strated rather uniform localization on all chromosomes. hCAP-G depicted axial localization at the midribs of both chromatids. $\beta$-Actin was distributed on chromosomes unevenly, with speckled intense signals at the periphery. Based on known information, mitochondrial and cytoplasmic proteins were clas- 


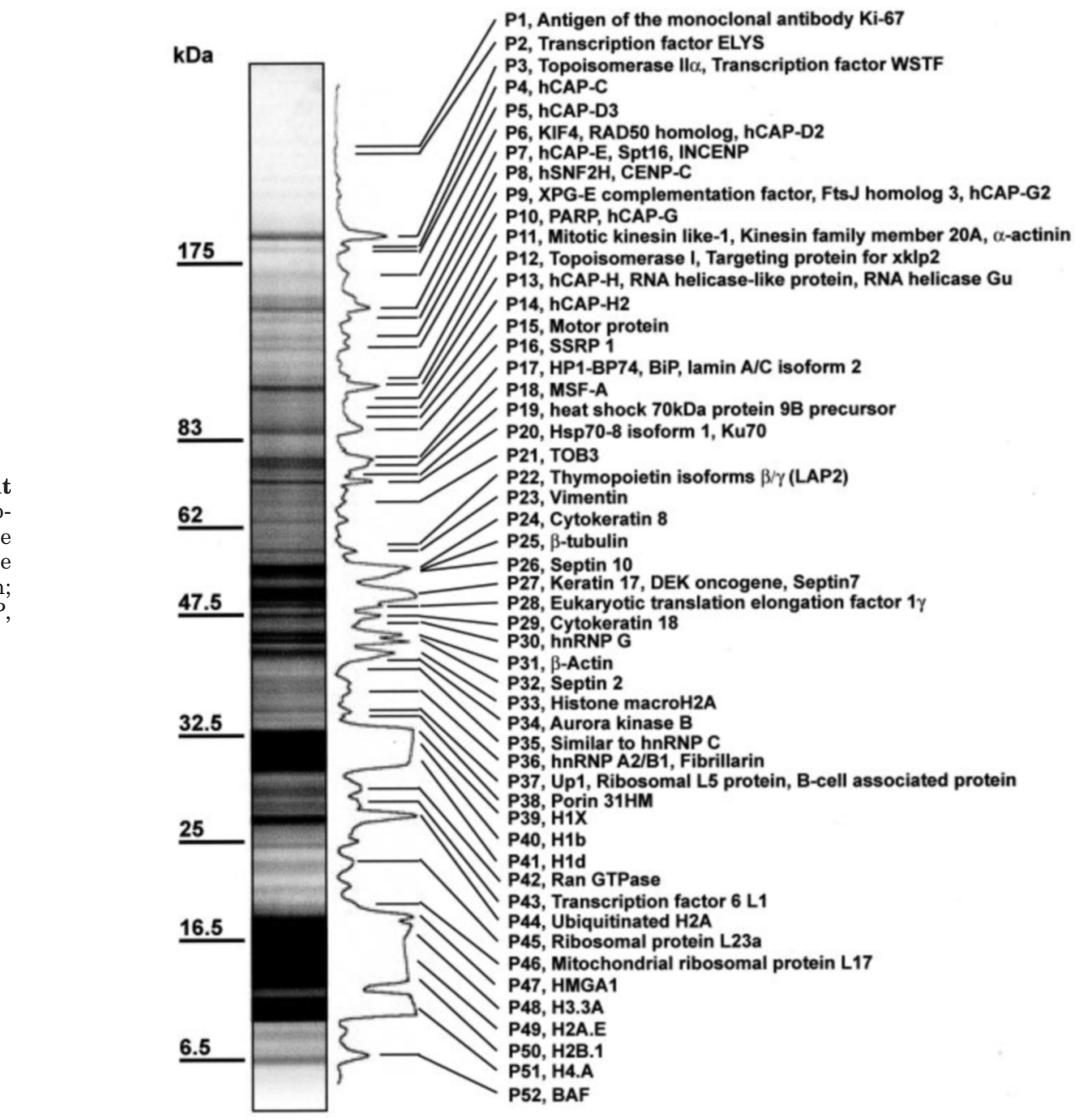

FIG. 6. Profiles of the constituent proteins of PG chromosomes. The proteins identified are indicated. The same number of proteins was also used in Table S3. INCENP, inner centromere protein; $C E N P-C$, centromere protein $\mathrm{C}$; $P A R P$, poly(ADP-ribose) polymerase. 1st

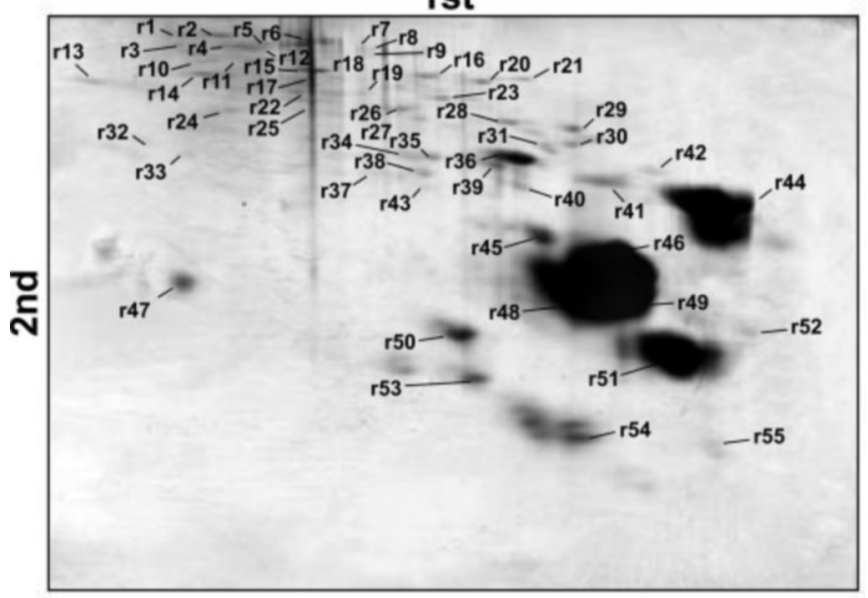

FIG. 7. RFHR two-dimensional gel electrophoresis patterns of proteins from PG chromosomes.

sified as one type of protein that was not localized on in vivo chromosomes with low affinity for isolated chromosomes. Furthermore, fibrous proteins such as $\beta$-actin, vimentin, and myosin consisted of one discrete type of protein.

\section{DISCUSSION}

To better define the protein constituent of metaphase chromosomes, the 157 proteins identified in PA and SG chromosomes and the 107 proteins in PG chromosomes were individ- ually compared based on the following three criteria: protein behavior during SDGC and Percoll density gradient centrifugation, localization of each protein on metaphase chromosomes, and information on functional and biochemical properties. The protein behavior enabled us to classify the identified proteins into two types as indicated above. Based on the results, all of the identified chromosomal proteins were newly classified into the following four groups: 1) chromosome coating proteins (CCPs), 2) chromosome peripheral proteins (CPPs), 3) chromosome structural proteins (CSPs), and 4) chromosome fibrous proteins (CFPs) (Fig. 9A).

CCPs - The amounts of CCPs decreased markedly in SG chromosomes and were low in PG chromosomes. CCPs are mainly mitochondrial and cytoplasmic proteins found in small amounts $(6.4 \%)$ but in a significant number $(49.7 \%, 79: 159)$ in PA chromosomes. Mitochondrial proteins with basic pI appear to be nonspecifically and weakly bound to chromosome surfaces during the chromosome isolation processes. The identified cytoplasmic proteins, including endoplasmic reticulum proteins, are mainly acidic. The $70-\mathrm{kDa}$ heat shock protein is a typical acidic and weak binding protein that was largely removed by SDGC (Fig. 3, $A$ and $C$, spot A4). The acidic proteins in PA chromosomes are likely to interact with the basic histones in the chromosome suspension. It appears that these proteins are not part of the chromosomes in living cells, where the subcellular organelles are maintained in their intact forms. The detergent used in the chromosome isolation causes the release of organelle proteins, thereby leading to their nonspecific binding to the surface of isolated chromosomes. 
TABLE I

A sample of the proteins identified in $P A, S G$, and $P G$ chromosomes

40 respective proteins out of the 159 identified in this work are shown in this list. Detailed information for all other proteins is provided in the Supplemental Material. Quantification of each spot was carried out with ImageMaster.

\begin{tabular}{|c|c|c|c|c|c|}
\hline No. ${ }^{a}$ & Protein & $\mathrm{p} 1$ & Mass & $\begin{array}{c}\mathrm{New} \\
\text { classification }\end{array}$ & $\begin{array}{c}\text { Localization at } \\
\text { interphase }^{b}\end{array}$ \\
\hline & & & $D a$ & & \\
\hline 9, A1 & 130-kDa leucine-rich protein & 5.4 & 145,109 & CCPs & $\mathrm{Cy}, \mathrm{Cs}, \mathrm{N}$ \\
\hline $18, \mathrm{~A} 4, \mathrm{R} 2, \mathrm{P} 19, \mathrm{r} 2$ & 70-kDa heat shock protein 9B (mortalin-2) & 6.0 & 73,682 & CCPs & $\mathrm{Cy}$ \\
\hline $20, \mathrm{~A} 8, \mathrm{R} 6$ & Chaperonin-60, Hsp60 & 5.7 & 61,016 & CCPs & $\mathrm{M}$ \\
\hline 2 & DNA-dependent protein kinase catalytic subunit & 6.9 & 465,266 & CPPs & $\mathrm{N}$ \\
\hline $\mathrm{R} 4, \mathrm{r} 6$ & Nucleolin & 4.59 & 76,298 & CPPs & $\mathrm{N}$ \\
\hline 17, P17 & Lamin A/C & 8.6 & 70,618 & CPPs & $\mathrm{N}$ \\
\hline $\mathrm{A} 16, \mathrm{R} 19, \mathrm{r} 10$ & hnRNP H1 & 5.9 & 49,198 & CPPs & $\mathrm{N}$ \\
\hline $23, \mathrm{~B} 12, \mathrm{R} 25, \mathrm{P} 30, \mathrm{r} 16$ & RNA-binding motif protein, $\mathrm{X}$ chromosome (hnRNP G) & 10.1 & 42,306 & CPPs & $\mathrm{N}$ \\
\hline 27, R32, P36, r23 & Fibrillarin & 10.2 & 33,407 & CPPs & $\mathrm{N}$ \\
\hline $\mathrm{R} 47, \mathrm{r} 31$ & Ribosomal protein $\mathrm{S} 6$ & 10.9 & 28,614 & CPPs & $\mathrm{R}$ \\
\hline $\mathrm{R} 17, \mathrm{r} 13$ & Nucleophosmin/B23.2 & 4.56 & 28,383 & CPPs & $\mathrm{N}$ \\
\hline P42 & Ran GTPase & 7.0 & 24,423 & CPPs & $\mathrm{N}, \mathrm{Cy}$ \\
\hline $42, \mathrm{P} 52, \mathrm{r} 47$ & BAF1 (barrier to autointegration factor-1) & 5.8 & 10,052 & CPPs & $\mathrm{N}$ \\
\hline 7, P3 & DNA topoisomerase II $\alpha$ & 8.8 & 174,286 & CSPs & $\mathrm{N}$ \\
\hline 7, P4 & hCAP-C & 6.6 & 137,978 & CSPs & $\mathrm{N}, \mathrm{Cy}$ \\
\hline P6 & $\mathrm{KIF} 4$ & 6.0 & 139,893 & CSPs & $\mathrm{N}$ \\
\hline P7 & hCAP-E & 8.7 & 135,696 & CSPs & $\mathrm{N}, \mathrm{Cy}$ \\
\hline P9 & MTB protein (hCAP-G2) & 6.4 & 130,876 & CSPs & $\mathrm{N}$ \\
\hline P9 & Xeroderma pigmentosum group $\mathrm{E}$ complementation factor & 5.1 & 126,831 & CSPs & $\mathrm{N}$ \\
\hline $10, \mathrm{P} 8$ & Human SNF2H & 8.3 & 121,828 & CSPs & $\mathrm{N}$ \\
\hline $12, \mathrm{P} 10$ & Poly(ADP-ribose) polymerase & 9.0 & 113,011 & CSPs & $\mathrm{N}$ \\
\hline P7 & Inner centromere protein & 9.5 & 105,500 & CSPs & $\mathrm{N}$ \\
\hline I5 & DNA topoisomerase I & 9.4 & 90,222 & CSPs & $\mathrm{N}$ \\
\hline $\mathrm{P} 13$ & KIAA0074 (hCAP-H) & 4.9 & 82,483 & CSPs & $\mathrm{N}$ \\
\hline P16, r9 & SSRP1 & 6.4 & 81,024 & CSPs & $\mathrm{N}$ \\
\hline $\mathrm{P} 12, \mathrm{r} 7$ & TPX2 (targeting protein for $x k l p 2$ ) & 9.5 & 80,939 & CFPs & $\mathrm{N}$ \\
\hline P33 & $\mathrm{MacroH} 2 \mathrm{~A}$ & 9.8 & 39,159 & CSPs & $\mathrm{N}$ \\
\hline r32 & HP1Hs- $\alpha$ & 5.71 & 22,080 & CSPs & $\mathrm{N}$ \\
\hline $\mathrm{B} 24, \mathrm{P} 40, \mathrm{r} 44$ & Histone $\mathrm{H} 1 \mathrm{~b}$ & 11.0 & 21,852 & CSPs & $\mathrm{N}$ \\
\hline $30, \mathrm{R} 65, \mathrm{P} 41, \mathrm{r} 44$ & Histone H1d & 10.9 & 21,352 & CSPs & $\mathrm{N}$ \\
\hline r33 & HP1 $\gamma$ & 5.23 & 20,798 & CSPs & $\mathrm{N}$ \\
\hline 41, B29, R82, P51, r51 & H4 histone family, member A & 11.7 & 11,360 & CSPs & $\mathrm{N}$ \\
\hline $37, \mathrm{R} 83, \mathrm{r} 53$ & HMGAI isoform $b$ & 10.3 & 10,673 & CSPs & $\mathrm{N}$ \\
\hline P11 & Mitotic kinesin-like protein-1 & 9.0 & 98,044 & CFPs & Cs \\
\hline $24, \mathrm{~A} 19, \mathrm{P} 31$ & $\beta$-Actin & 5.5 & 40,978 & CFPs & $\mathrm{Cs}, \mathrm{N}$ \\
\hline
\end{tabular}

${ }^{a}$ Numbers correspond to bands in one-dimensional SDS-PAGE and spots IEF and spots in (A, pI 4-7); and (B, pI 6-11) and RFHR (R and r) two-dimensional electrophoresis analyses.

${ }^{b} \mathrm{~N}$, nucleus; M, mitochondrial; Cy, cytoplasmic; Cs, cytoskeleton; r, ribosome.

CPPs-Nuclear proteins have thus been classified into two new groups, viz. CPPs and CSPs. Proteins classified as CPPs are mainly nucleolar and nuclear envelope-related proteins. They were partly removed by SDGC. However, most of the CPPs that were identified in PA and SG chromosomes in significant amounts were also identified in PG chromosomes, thus indicating that they are the essential proteins for metaphase chromosomes. Proteins in this group were the second frequently identified proteins $(28 \%)$ in PG chromosomes. From the beginning of chromosome research, the existence of CPPs was visually detected, and they were referred to as the "chromosome matrix" or "chromosome sheath" (43). In mitotic prometaphase, the nucleolus disappears after the breakdown of the nuclear envelope (1). The existence of fibrillarin at the chromosome periphery has already been reported $(1,17)$. Other nucleolar proteins such as hnRNPs have also been detected. Proteins related to nucleolar formation, ribosome biogenesis, mRNA turnover, and nuclear envelope formation may localize to the chromosome peripheral region during mitosis and function at the end of telophase and at the onset of interphase. Fibrillarin, hnRNPs, BAF, lamin A/C, Ki-67, and the DNA-dependent protein kinase catalytic subunit are examples of CPPs (Tables S1 and S2). The proteins of the nuclear envelope in interphase, $\mathrm{BAF}$ and lamin $\mathrm{A} / \mathrm{C}$, are localized primarily on the chromosome in anaphase/telophase (44). The DNA-dependent protein kinase catalytic subunits involved in a variety of biological functions such as DNA repair and telomere mainte- nance were also classified in this category $(45,46)$. CPPs identified in $\mathrm{PG}$ chromosomes included proteins for telomere composition. Although hnRNP A2/B1 is a component of the telomere complex (47) and Ku70 is involved in telomere maintenance (48), their localization in metaphase is not only in the telomeric region, but also in the entire peripheral region of metaphase chromosomes (49). This fact presents an interesting dynamic feature of telomere proteins in action. Presumably, they are pooled in the peripheral region as CPPs and function in the telomeric region of metaphase chromosomes.

Some ribosomal proteins were still found in SG and PG chromosomes, indicating the existence of certain ribosomal proteins that are different from ordinary ribosomal proteins classified as CCPs. This view is supported by reports in which ribosomal protein $\mathrm{S} 1$ was localized to the chromosome peripheral region (17) and ribosomal protein S6 was a component of RNP complexes (50).

CSPS-Because CSPs form the body of chromosomes and play a role in the condensation/decondensation of chromosomes (1), they should be common to PA, SG, and PG chromosomes. More than half of the number $(57.5 \%, 27: 47)$ of the nuclear proteins identified in PA chromosomes belonged to this group, and CSPs amounted to $>80 \%$ of the PA chromosomal proteins (Fig. 9B). CSPs were most frequently $(40.2 \%)$ identified in PG chromosomes among the three types of chromosomes analyzed. Core and linker histones were naturally identified; a histone variant, macroH2A (51), and a post-translationally modified 
histone, ubiquitinated H2A (52), were also identified in all three types of isolated chromosomes. Significant amounts of macroH2A (Fig. 2A, band 25; and Fig. 6, band P33) were expected because this variant is known to localize on chromosomes during mitosis, overlapping with histone H3 methylated at Lys $^{4}$ (53). HMGN2 and HMGA1 were the second and third most abundant proteins, respectively. These results suggest an important structural role of these particular HMG proteins,

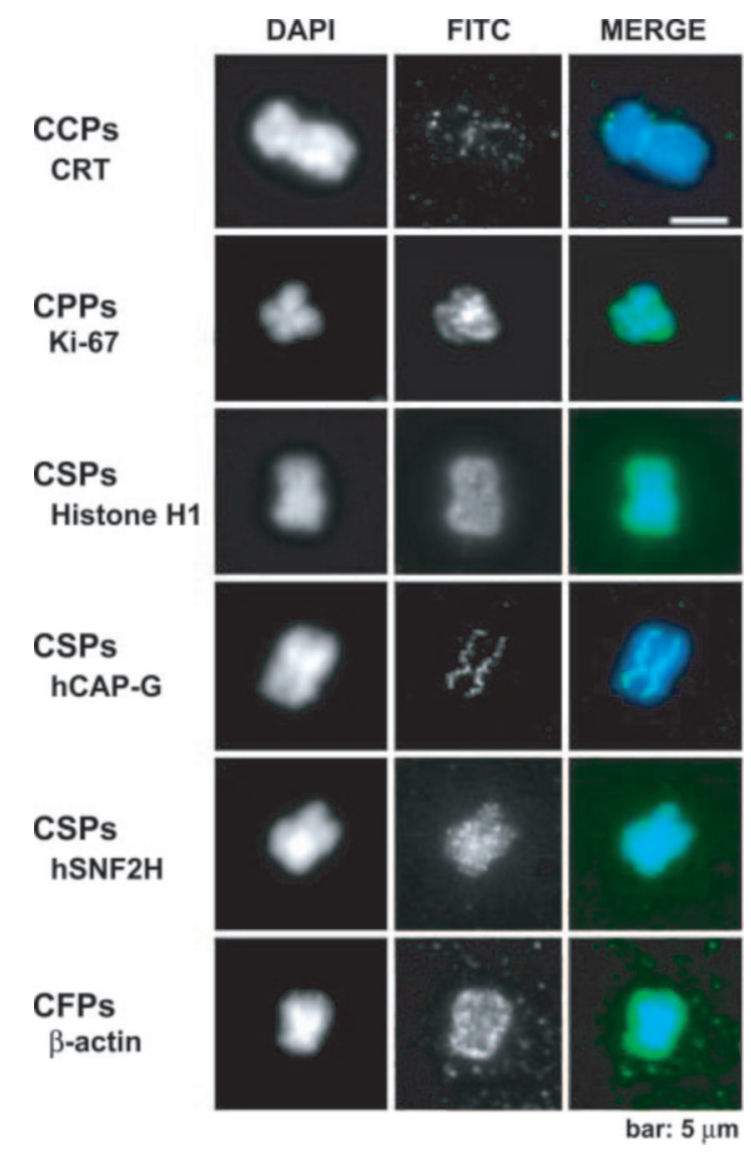

FIG. 8. Indirect immunofluorescence microscopy of the representative proteins classified. The staining patterns of isolated chromosomes are indicated. Left panels, 4',6-diamidino-2-phenylindole (DAPI); middle panels, fluorescein isothiocyanate (FITC); right panels, merged. CCPs, CPPs, CSPs, and CFPs are the new classification of chromosomal proteins used in this study. CRT, calreticulin; $h S N F 2 H$, human SNF2H. which is further supported by their high affinity for the chromatin fiber compared with other HMGs such as HMGB (54, 55). Poly(ADP-ribose) polymerase, hSNF2H, and the DEK oncogene protein were identified (Fig. $2, A$ and $B$ ). Inner centromere protein and Aurora B identified in PG chromosomes are known as chromosome passenger proteins and are localized to the centromeric region in metaphase (56). A new passenger protein recently reported, Borealin (57), also named Dasra B (58), was also identified as CDCA8 in this study. Localization of poly(ADP-ribose) polymerase on the centromere, neocentromere, and chromosome arm has already been reported (59). One of the features emerging from analyses using the three types of chromosomes was that not all components of the centromeric/kinetochoric and telomeric regions of chromosome were detected, although several proteins that concentrate in the centromeric region during mitosis, such as chromosome passenger proteins and heterochromatin protein-1 $\gamma(60)$, were identified. Centromere protein $\mathrm{C}$ was the only protein among centromere proteins identified sporadically in this study. These facts reasonably suggest that centromere/kinetochore and telomere proteins are present only in small amounts compared with the overall chromosomal proteins. In fact, the quantitative purification of centromere protein A and telomeric repeat-binding factor-1 from human cells revealed markedly small molar amounts of $\sim 1: 70,000$ and 1:100,000 histone H4, respectively $(61,62)$.

All eight subunits of the condensin I and II complexes (24, 25) were identified in PG chromosomes, although previous analyses of the human metaphase chromosome scaffold did not detect two of them, hCAP-D3 and hCAP-H2 (63, 64). Using a human mitotic cell extract, Takemoto et al. (65) reported that one condensin complex is present per 13 kilobase pairs of DNA. Assuming that one nucleosome is present in every $200 \mathrm{bp}$ of DNA, this would imply that the molecular number of the condensin complex/100 histone $\mathrm{H} 4$ molecules is 0.77 . Considering the molecular mass of hCAP-C $(138 \mathrm{kDa})$ and that of histone H4 $(11 \mathrm{kDa})$, the band intensity of hCAP-C should be approximately one-tenth that of histone H4. However, the band of hCAP-C in the one-dimensional SDS-PAGE pattern was considerably weaker than that expected from this estimation (Fig. 6 , band P4). Based on the band intensity, the molar ratio of hCAP-C to 100 molecules of histone $\mathrm{H} 4$ is 0.32 at the most, which means they bind to chromatin fiber every 33 kilobase pairs on average. This discrepancy may be explained by the dissociation of the condensin subunits from metaphase chromosomes during the isolation procedures, despite the fact that
FIG. 9. A, schematic representation of the metaphase chromosome from the constituent protein perspective. Proteins have been newly classified into the following four groups: CCPs, CPPs, CSPs, and CFPs. $B$, the percentages of proteins classified into four groups, which were estimated based on the number of proteins identified in PA (upper) and PG (lower) chromosomes. Inset (upper), estimation based on the molar amounts.
A

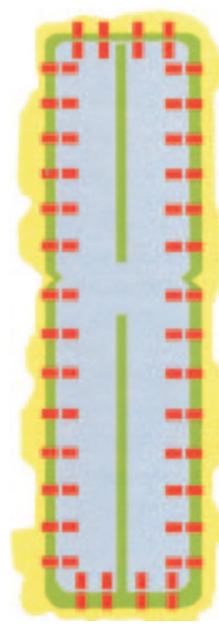

B

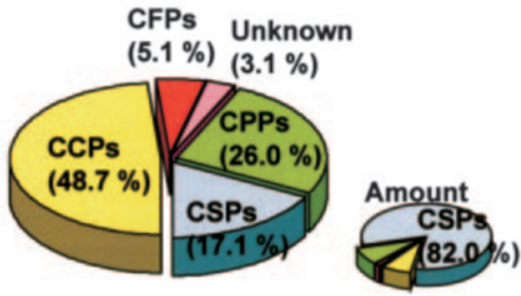

PA chromosomes (158 proteins) related

Nucleolus Ribosome

csps

Topoisomerases Condensin Passenger $n=$ CFPs Cytoskeleton

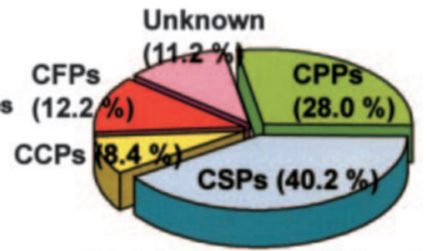

PG chromosomes (107 proteins) 
the isolated chromosomes retained the axial distribution of the condensin subunit (hCAP-G) in chromosomes (Fig. 8 and Figs. S2 and S3) and the native morphology when observed by optical microscopy. It has been reported that condensin subunits dissociate from metaphase chromosomes in the absence of divalent cations (9) or ATPase inhibitors (37).

CFPs-CFPs were classified primarily as an independent group because they are fibrous in nature and because their amounts were not changed in both PA and SG chromosomes, e.g. the spot intensity of $\beta$-actin did not change significantly (Fig. 3, $A$ and $C$, spot A19). Mitotic kinesin-like protein, which interacts with the mitotic spindle, has also been classified into this group (66). Among 18 different CFPs, $\beta$-actin, vimentin, and tubulin were even identified in PG chromosomes (Fig. 6), which differs from a previous report (32). The contribution of CFPs to chromosome structure is still ambiguous (67). Myosin I was not identified in this study, although its localization in the nucleus has been reported (68). Myosin II, tubulin, and actin have been shown to be involved in chromosome segregation during mitosis (69). Nuclear injection of anti-actin antibodies into Xenopus oocytes blocks chromosome condensation (70) and causes the retraction of lampbrush chromosomes in salamander nuclei (71). Furthermore, $\beta$-actin is one of the components of the chromatin-remodeling SWI/SNF-like BAF complex (72). When all of these facts are considered together, it can be assumed that $\beta$-actin would be tightly bound to metaphase chromosomes and would play a definite structural role. Our observations obtained by indirect immunofluorescence microscopy indicated for the first time the localization of $\beta$-actin to metaphase chromosomes (Fig. 8). Mandeville and Rieder (73) have reported that metaphase chromosomes are surrounded by a "cage" of keratin filaments that restrict the dispersion of chromosomes during the breakdown of the nuclear envelope or microtubule penetration between and through the chromosomes. Thus, the CFPs that maintain the spatial organization of chromosomes within a mitotic cell are also likely to be bound to chromosomes in vivo.

Candidates for Novel Chromosomal Proteins-Fifteen proteins that were not classified into any of the four groups were identified in PA, SG, and/or PG chromosomes. To our knowledge, chromosomal localization of these proteins has not been reported before; thus, they could be novel chromosomal proteins.

Conclusion-We have provided a qualitative and quantitative identification of all of the major chromosomal proteins of isolated human metaphase chromosomes. Comparative proteome analyses of the chromosomes obtained by the three types of isolation procedures enabled us to differentiate chromosomal proteins as intrinsic chromosomal proteins or possible attachment proteins during the isolation procedures. The proteins identified here could be classified into four major different groups based on a combination of the results from the comparative proteome and localization analyses. A four-layer model of the metaphase chromosome has been developed in which most of the chromosomal proteins are allocated to one of the four layers; coating, peripheral, structural, and fibrous. Therefore, this study provides an important reference for future studies on chromosome structure and function.

Acknowledgments-We are grateful to Juan Ausio (University of Victoria) and Jordanka Zlatanova (University of Wyoming) for helpful discussions and critically reading the manuscript. We thank Akio Kobayashi and Eiichiro Fukusaki (Osaka University) for access to the liquid chromatography-MS/MS instrument and Akira Wada and Hideji Yoshida (Osaka Medical University) for technical help in RFHR two-dimensional gel electrophoresis experiments. We thank Keiji Kimura (RIKEN Institute) and Fumio Hanaoka (Osaka University) for anti-hCAP antibodies. We also thank Sumire Inaga (Tottori University) for using the SEM picture of metaphase chromosomes with slight modification.

\section{REFERENCES}

1. Sumner, A. T. (2003) Chromosomes: Organization and Function, pp. 5-142, Blackwell Publishing Ltd., Oxford

2. Flemming, W. (1882) Zellsubstanz, Kern und Zelltheilung, Verlag Vogel, Leipzig, Germany

3. van Holde, K. E. (1988) Chromatin, pp. 69-343, Springer-Verlag, Berlin

4. Turner, B. (2002) Chromatin and Gene Regulation: Mechanisms in Epigenetics, pp. 44-93, Blackwell Publishing Ltd., Oxford

5. Arents, G., and Moudrianakis, E. (1993) Proc. Natl. Acad. Sci. U. S. A. 90, 10489-10493

6. Ausio, J. (2000) Biophys. Chem. 86, 141-153

7. Tsanev, R., Russev, G., Pashev, I., and Zlatanova, J. (1992) Replication and Transcription of Chromatin, CRC Press LLC, Boca Raton, FL

8. Luger, K., Mader, A., Richmond, R., Sargent, D., and Richmond, T. (1997) Nature 389, 251-260

9. Lewis, C., and Laemmli, U. K. (1982) Cell 29, 171-181

10. Marsden, M., and Laemmli, U. K. (1979) Cell 17, 849-858

11. Gasser, S., Laroche, T., Falquet, J., Boy de la Tour, E., and Laemmli, U. K. (1986) J. Mol. Biol. 188, 613-629

12. Saitoh, N., Goldberg, I., Wood, E., and Earnshaw, W. (1994) J. Cell Biol. 127, $303-318$

13. Swedlow, J., Sedat, J., and Agard, D. (1993) Cell 73, 97-108

14. Sumner, A. T. (1996) Chromosome Res. 4, 5-14

15. Christensen, M., Larsen, M., Barthelmes, H., Hock, R., Andersen, C., Kjeldsen, E. Knudsen, B., Westergaard, O., Boege, F., and Mielke, C. (2002) J. Cell Biol. 157, 31-44

16. Tavormina, P., Come, M., Hudson, J., Mo, Y., Beck, W., and Gorbsky, G. (2002) J. Cell Biol. 158, 23-29

17. Hernandez-Verdun, D., and Gautier, T. (1994) BioEssays 16, 179-185

18. Yasuda, Y., and Maul, G. (1990) Chromosoma (Berl.) 99, 152-160

19. Wachtler, F., and Stahl, A. (1993) Micron 24, 473-505

20. Cooke, C., Heck, M., and Earnshaw, W. (1987) J. Cell Biol. 105, 2053-2067

21. Masumoto, H., Masukata, H., Muro, Y., Nozaki, N., and Okazaki, T. (1989) J. Cell Biol. 109, 1963-1973

22. Sugata, N., Li, S., Earnshaw, W., Yen, T., Yoda, K., Masumoto, H., Munekata, E., Warburton, P., and Todokoro, K. (2000) Hum. Mol. Genet. 9, 2919-2926

23. Nakayama, J., Saito, M., Nakamura, H., Matuura, A., and Ishikawa, F. (1997) Cell 88, 875-884

24. Hirano, T., and Mitchison, T. J. (1994) Cell 79, 449-458

25. Ono, T., Losada, A., Hirano, M., Myers, M., Neuwald, A., and Hirano, T. (2003) Cell 115, 109-121

26. Poirier, M., Eroglu, S., Chatenay, D., and Marko, J. (2000) Mol. Biol. Cell 11, 269-276

27. Poirier, M., and Marko, J. (2002) Proc. Natl. Acad. Sci. U. S. A. 99, 15393-15397

28. Sone, T., Iwano, M., Kobayashi, S., Ishihara, T., Hori, N., Takata, H., Ushiki, T., Uchiyama, S., and Fukui, K. (2002) Arch. Histol. Cytol. 65, 445-455

29. Uchiyama, S., Kobayashi, S., Takata, H., Ishihara, T., Sone, T., Matsunaga, S., and Fukui, K. (2004) Cytogenet. Genome Res. 107, 49-55

30. Spector, D., Goldman, R., and Leinwamd, L. (1998) in Cells: A Laboratory Manual (Janssen, K., ed) Vol. 49, pp. 11-12, Cold Spring Harbor Laboratory, Cold Spring Harbor, NY

31. Wada, A. (1986) J. Biochem. (Tokyo) 100, 1583-1594

32. Gasser, S., and Laemmli, U. K. (1987) Exp. Cell Res. 173, 85-98

33. Cole, A. (1967) Theor. Biophys. 1, 305-375

34. Hardy, S. J., Kurland, C., Voynow, P., and Mora, G. (1969) Biochemistry 8, 2897-2905

35. Suckau, D., Resemann, A., Schuerenberg, M., Hufnagel, P., Franzen, J., and Holle, A. (2003) Anal. Bioanal. Chem. 376, 952-965

36. Kimura, K., Cuvier, O., and Hirano, T. (2001) J. Biol. Chem. 276, 5417-5420

37. Maeshima, K., and Laemmli, U. K. (2003) Dev. Cell 4, 467-480

38. Losada, A., Hirano, M., and Hirano, T. (1998) Genes Dev. 12, 1986-1997

39. Dellaire, G., Farrall, R., and Bickmore, W. (2003) Nucleic Acids Res. 31, $328-330$

40. Chiu, M. (1982) Biochim. Biophys. Acta 699, 110-120

41. Chiu, M., and Irvin, J. (1983) Biochim. Biophys. Acta 740, 342-345

42. Albright, S., Nelson, P., and Garrard, W. (1979) J. Biol. Chem. 254, 1065-1073

43. Sharp, L. (1929) Bot. Gaz. 88, 349

44. Haraguchi, T., Koujin, T., Segura-Totten, M., Lee, K. K., Matsuoka, Y. Yoneda, Y., Wilson, K., and Hiraoka, Y. (2001) J. Cell Sci. 12, 4575-4585

45. Dynan, W., and Yoo, S. (1998) Nucleic Acids Res. 26, 1551-1559

46. Featherstone, C., and Jackson, S. (1999) Curr. Biol. 9, 759-761

47. Kanoh, J., and Ishikawa, F. (2003) CMLS Cell. Mol. Life Sci. 60, 2295-2302

48. Krecic, A., and Swanson, M. S. (1999) Curr. Opin. Cell Biol. 11, 363-371

49. Snee, M., Kidd, G. J., Munro, T. P., and Smith, R. (2002) J. Cell Sci. 115, 4661-4669

50. Pinol-Roma, S. (1999) Mol. Biol. Cell 10, 77-90

51. Pehrson, J. R., and Fried, V. A. (1992) Science 257, 1398-1400

52. Moore, S. C., Jason, L., and Ausio, J. (2002) Biochem. Cell Biol. 80, 311-319

53. Chadwick, B., and Willard, H. (2002) J. Cell Biol. 157, 1113-1123

54. Kuehl, L., Salmond, B., and Tran, L. (1984) J. Cell Biol. 99, 648-654

55. Pallier, C., Scaffidi, P., Chopineau-Proust, S., Agresti, A., Nordmann, P., Bianchi, M., and Marechal, V. (2003) Mol. Biol. Cell 14, 3414-3426

56. Adams, R. R., Carmena, M., and Earnshaw, W. C. (2001) Trends Cell Biol. 11, $49-54$

57. Gassmann, R., Carvalho, A., Henzing, A. J., Ruchaud, S., Hudson, D. F. Honda, R., Nigg, E. A., Gerloff, D. L., and Earnshaw, W. C. (2004) J. Cell Biol. 166, 179-191

58. Sampath, S. C., Ohi, R., Leismann, O., Salic, A., Pozniakovski, A., and Funabiki, H. (2004) Cell 118, 187-202

59. Earle, E., Saxena, A., MacDonald, A., Hudson, D. F., Shaffer, L. G., Saffery, R. Cancilla, M. R., Cutts, S. M., Howman, E., and Choo, K. H. (2000) Hum. Mol. Genet. 22, 187-194 
60. Hayakawa, T., Haraguchi, T., Masumoto, H., and Hiraoka, Y. (2003) J. Cell Sci. 116, 3327-3338

61. Martinez, A., Sun, D., Billings, P. B., Swiderek, K. M., Sullivan, K. F., and Hoch, S. O. (1998) J. Autoimmun. 11, 611-619

62. Tempst, P., and de Lange, T. (1995) Science 270, 1663-1667

63. Morrison, C., Henzig A., Jensen, O., Osheroff, N., Dodson, H., Kandels-Lewis, S., Adams, R., and Earnshaw, W. (2002) Nucleic Acids Res. 30, 5318-5327

64. Gassmann, R., Henzing, A. J., and Earnshaw, W. C. (2004) Chromosoma (Berl.) 113, 385-397

65. Takemoto, A., Kimura, K., Yokoyama, S., and Hanaoka, F. (2004) J. Biol. Chem. 279, 4551-4559

66. Nislow, C., Lombillo, V. A., Kuriyama, R., and McIntosh, J. R. (1992) Nature
359, 543-547

67. Pederson, T., and Aebi, U. (2002) J. Struct. Biol. 140, 3-9

68. Pestic-Dragovich, L., Stojiljkovic, L., Philimonenko, A., Nowak, G., Ke, Y., Settlage, R., Shabanowitz, J., Hunt, D. F., Hozak, P., and de Lanerolle, P. (2000) Science 290, 337-341

69. Scholey, J. M., Brust-Mascher, I., and Mogilner, A. (2003) Nature 422, $746-752$

70. Rungger, D., Rungger-Brandle, E., Chaponnier, C., and Gabbiani, G. (1979) Nature 282, 320-321

71. Scheer, U., Hinssen, H., Franke, W., and Jockusch, B. (1984) Cell 39, 111-122 72. Zhao, K., and Wang, W. (1998) Cell 95, 625-636

73. Mandeville, E. C., and Rieder, C. L. (1990) Cell Motil. Cytoskeleton 15, 111-120 